\title{
Codfish vertebra sign
}

\author{
Osama S M Amin
}

Department of Medicine, International Medical University School of Medicine, Negeri Sembilan, Malaysia

\section{Correspondence to} Dr Osama S M Amin, dr.osama.amin@gmail.com

Accepted 17 February 2017

\section{DESCRIPTION}

A woman aged 70 years presented with several years' history of low back pain and bilateral lower limb pains. Her menstrual cycles ceased when she was 44 years of age. Plain X-ray of the lumbosacral spine revealed diffuse osteoporotic changes (figure 1). A battery of investigations was performed; the only abnormal results were slightly raised serum alkaline phosphatase (probably from vertebral fractures) and very low-serum 25-hydroxyvitmain D. Lumbosacral spine MRI was

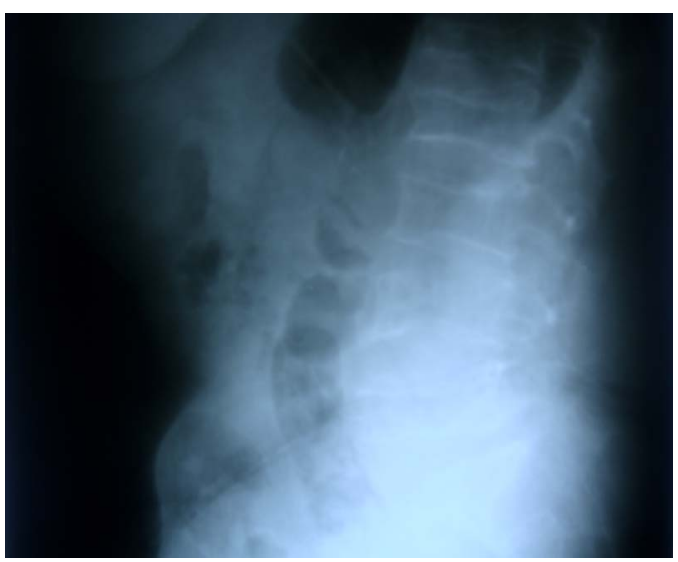

Figure 1 Lateral X-ray film of the lumbar spine, which reveals biconcavity of the lumbar vertebrae and osteopenia.

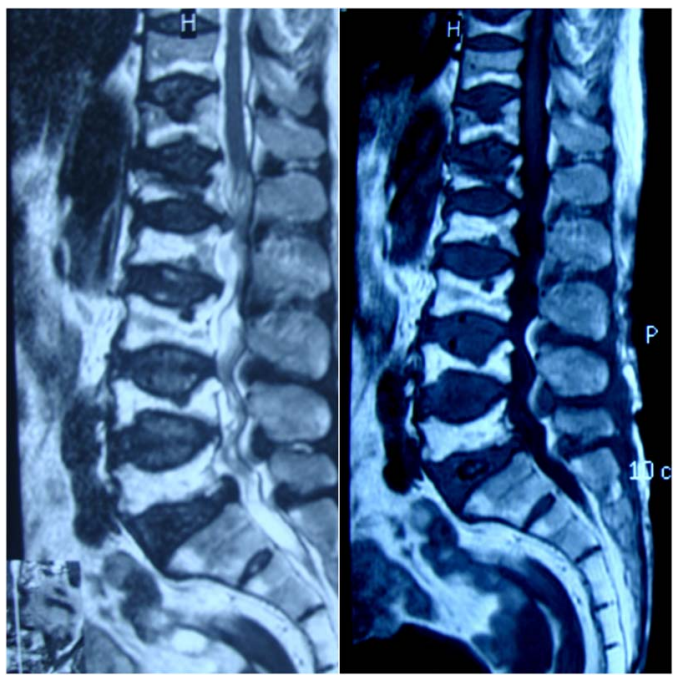

Figure 2 Sagittal T1-weighted (right) and T2-weighted (left) MRI of the lumbosacral spine. The D10-12 vertebrae are also seen. All vertebral bodies show biconcave deformity of their endplates with areas of rounded depressions and impressions, different signal intensities of the vertebral body and bone marrow, and loss of more than $40 \%$ of the vertebral height. This is severe osteoporosis showing different stages of bony collapse. ordered (figure 2) and revealed several codfish vertebrae in addition to lumber spinal stenosis. Dual X-ray absorptiometry revealed a T-score of -2.9 at the spine. The patient's diagnosis was postmenopausal osteoporosis.

In 1941, the American endocrinologist Fuller Albright described the biconcave deformity of vertebral bodies in postmenopausal women. $\mathrm{He}$ coined the term 'fish vertebrae' because of their similarity to the shape of fish vertebrae. However, he did not speciate the fish's type. After 7 years, he and his colleague Edward Reinfenstein used the term 'codfish vertebrae' instead. The codfish vertebra sign refers to a characteristic smooth biconcave deformity of the vertebral bodies; squared-off depressions of the end-plates combined with compressions from the adjacent discs create this image. Spinal MRI studies can differentiate between acute, subacute and chronic osteoporotic fractures as well between osteoporosis and other spinal degenerative diseases. It may also suggest other causes of codfish vertebrae, for example, sickle cell disease, renal osteodystrophy and thalassaemia major. Therefore, codfish vertebra is not pathognomonic of postmenopausal osteoporosis; it is more common than anterior vertebral wedging and flat vertebrae. ${ }^{1-3}$

\section{Learning points}

- 'Codfish vertebra' refers to the biconcave deformity of the vertebral body and is more common than anterior vertebral wedging and flat vertebra signs.

- It is not pathognomonic of postmenopausal osteoporosis and can be seen in other conditions and secondary causes of osteoporosis.

- Spinal MRI can delineate these codfish vertebrae, estimate the age of osteoporotic fractures, diagnose other causes behind the development of this sign and differentiate osteoporosis from other spinal degenerative disease.

Competing interests None declared.

Patient consent Obtained.

Provenance and peer review Not commissioned; externally pee reviewed.

\section{REFERENCES}

1 Murphy WA Jr, DiVito DM. Fuller Albright, postmenopausal osteoporosis, and fish vertebrae. Radiology 2013;268:323-6.

2 Ntagiopoulos PG, Moutzouris DA, Manetas S. The 'fish-vertebra' sign. Emerg Med J 2007;24:674-5

3 Yamato M, Nishimura G, Kuramochi E, et al. MR appearance at different ages of osteoporotic compression fractures of the vertebrae. Radiat Med 1998;16:329-34. 
Copyright 2017 BMJ Publishing Group. All rights reserved. For permission to reuse any of this content visit http://group.bmj.com/group/rights-licensing/permissions.

BMJ Case Report Fellows may re-use this article for personal use and teaching without any further permission.

Become a Fellow of BMJ Case Reports today and you can:

- Submit as many cases as you like

- Enjoy fast sympathetic peer review and rapid publication of accepted articles

- Access all the published articles

- Re-use any of the published material for personal use and teaching without further permission

For information on Institutional Fellowships contact consortiasales@bmjgroup.com

Visit casereports.bmj.com for more articles like this and to become a Fellow 